\title{
Influence of Store Satisfaction, Merchandise Quality, and Service Quality on Store Loyalty
}

\author{
N. R. V. Ramana Reddy, T. N. Reddy, and B. Abdul Azeem,
}

\begin{abstract}
Loyalty is a phenomenon that has always received a great deal of interest among marketers, specifically from retailing side. The study tries to further the understanding towards this phenomenon by trying to test the inclusion of (merchandise and service) quality, and satisfaction as the determinants of store loyalty. The paper tries to answer the question whether merchandise quality and service quality are independently associated with store loyalty along with customer satisfaction or associated through interaction. Specifically, the present work aims to study the role of merchandise quality, amidst store satisfaction and service quality, in the formation of store loyalty. Hierarchical regression is employed to test the drawn hypotheses. The findings of the study indicate that service quality, and customer satisfaction show significant influence on store loyalty. The merchandise quality does not show significant influence on store loyalty. But the interactive effect of merchandise quality and service quality is found to improve the model. The results of the study help in identifying the factors which are more important to focus in strategizing issues related to store loyalty in a more specific manner.
\end{abstract}

Index Terms-Store loyalty, Customer satisfaction, Merchandise quality, Service quality, Retailing.

\section{INTRODUCTION}

Loyalty is a phenomenon that has always received a great deal of interest among marketers, and store loyalty is the most initial variable of interest to retailers. The reasons are that loyal store customers spend more in total. They direct a higher proportion of their expenditure to their main store, are less likely to switch stores, and may be more tolerant of higher prices. Thus, stores that attract a high proportion of loyal customers may benefit from higher returns per customer and from greater stability in their customer base. First, however, retailers need to know what determines customer loyalty.

Most of the studies examined the relationship between store loyalty and long-term performance of a firm, [1]-[4] but agreement over the drivers or determinants of store loyalty is still in great discussion. For example, Heskett et al, [4] in their conceptual model of the service-profit chain, believed

Manuscript received October 10, 2010; revised September 13, 2011.

Dr. N. R. V. Ramana Reddy (Principal) is with the Annamacharya PG College of Management Studies, Rajampet, Andhra Pradesh, India 516126 (Corresponding author; phone: +919848998647; fax: +91-8565-200242; e-mail: aitsap@yahoo.co.in).

Dr. T. N. Reddy (Head - Dept. of Humanities) is with JNTU College of Engineering, Pulivendula, Andhra Pradesh, India (e-mail: tnreddy_jntu@yahoo.co.in).

B. Abdul Azeem is with the Annamacharya PG College of Management Studies, Rajampet, Andhra Pradesh, India 516126 (e-mail: babdul.azeem@gmail.com). that customer satisfaction was the driver of customer loyalty. Yet, Jones and Sasser [3] provides examples of when customer satisfaction does not lead to loyal customers and found that brand image and product quality were more important drivers of customer loyalty.

This research aims to identify the effects of store satisfaction, merchandise quality and service quality as the determinants of store loyalty in the context of Indian organized retailing. These determinants have been shown to be antecedents of store loyalty by Oliver [5], Yavas and Babakus [6], and Toyin et al. [7] on store loyalty.

\section{LITERATURE REVIEW}

\section{A. Store Loyalty}

Based originally on the concept of brand loyalty, at the store level, store loyalty refers to the tendency to repeat purchase at the same store (for similar or other products) [8]. Bloemer and Ruyter [9], in conceptualizing store loyalty, distinguish between repeat visiting behavior and store loyalty. Following Jacoby and Chestnut [10], Bloemer and Ruyter [9] define store loyalty as:

The biased (i.e. non random) behavioral response (i.e. revisit), expressed over time, by some decision-making unit with respect to one store out of a set of stores, which is a function of psychological (decision making and evaluative) processes resulting in brand commitment.

The critical element of this definition is store commitment. Bloemer and Ruyter [9] propose that for store loyalty to occur, store commitment is the necessary condition and the absence of which leads to spurious loyalty. A consumer becomes committed to the store and, thereby, becomes store loyal based on the explicit and extensive decision making as well as evaluative processes done towards the considered store [9].

Previous studies view customer loyalty as being both behavioral and attitudinal [11]-[12]. In measuring retail store loyalty, the attitudinal component of loyalty is operationalized as commitment and the behavioral dimension as repeat purchase and positive word-of-mouth [9], [13]. Bridson, Evans and Hickman [14] justify the use of both the behavioral and attitudinal aspects for a more holistic representation of the construct, with the multi-dimensional definition providing greater insight into consumer loyalty motivations than either component in isolation.

A review of the customer loyalty literature reveals that bulk of the studies primarily focuses on the concept of loyalty for tangible goods at the brand level [15]. Studies at the store level focus primarily on store satisfaction in the formation of store loyalty [6], [9], [16], [17]. Simultaneous examination of the two critical dimensions of perceived quality (merchandise quality and service quality) as antecedents of customer 
loyalty (e.g., loyalty to a store) lags behind [18]. Hence, in this study we try to bring these three factors - store satisfaction, merchandise quality and service quality together to further the understanding of store loyalty.

\section{B. Store Satisfaction}

The basis on which overall marketing concept stands is on the identification and satisfaction of customer needs leading to improved customer retention [19]. Studies show varied definitions for the concept of satisfaction. Bloemer and Ruyter [9] defined store satisfaction as the outcome of the subjective evaluation that the chosen alternative (the store) meets or exceeds expectations. This definition is based on the expectancy disconfirmation paradigm [20]-[22]. According to this paradigm, satisfaction results when customer expectations confirm the perceived store performance. Dissatisfaction occurs when customer expectations disconfirm the perceived store performance. A number of authors view satisfaction as end-state-types [16]: satisfaction-as-contentment, satisfaction-as-pleasure, satisfaction-as-relief, satisfaction-as-novelty and satisfaction-as-surprise.

Store loyalty is being increasingly recognized as the ultimate objective of the store satisfaction measures. It is argued that higher the customer satisfaction, more will be the loyalty of customers to a store and higher the customer protection from competition [23]. While there has been debate as to whether different degrees of satisfaction have a stronger influence over the obtainment of loyalty [9], it is generally accepted that customer loyalty is determined to a large extent by customer satisfaction [24].

\section{Merchandise Quality}

Yavas and Babakus [6] identified, in a study done on national retailer, that merchandise quality is the second most important antecedent in the formation of store loyalty. In a study to identify perceived quality constructs of consumers' durable goods, perceived merchandise quality played a crucial role affecting the purchase choices [25]. Cronin, Brady and Hult [26] also indicated the importance of merchandise quality on consumer decision making. But the importance of the merchandise quality influences on satisfaction and store loyalty are largely ignored [27]. As a consequence, this study considers merchandise quality as an antecedent and investigates its effect on store loyalty.

In a study to explore the effect of perceived quality of gasoline on consumer satisfaction and loyalty towards gas stations in Taiwan, Lee [28] identified that perceived merchandise quality not only affects on consumer satisfaction, but also influenced directly on consumer loyalty. In fact, perceived merchandise quality had a stronger impact on customer loyalty than did satisfaction. Based on the findings of Lee [28], the present study proposes to investigate the interactive relationship of merchandise quality (with satisfaction) and store loyalty.

\section{Service Quality}

Service quality is considered as the most important organization performance indicator both at the marketing literature generally and the service marketing literature specifically [29]. A number of models of service quality have emerged in the literature. Two important service quality models are those of Gronroos [30] and Parasuraman et al. [31], [32]. Several authors have included service quality in their models to explain loyalty or retention [26], [33]-[35]. These authors strongly believe that service quality positively affects important behavioral outcomes such as loyalty. Zahorik and Rust [36] argue that modeling perceived quality as an influencing factor of customer loyalty will provide significant diagnostic ability to any framework that includes customer loyalty as a dependent construct.

In most service industry marketing literature, perceived service quality captures the spot light, while perceived merchandise quality is absent. For most industries providing, intangible services and tangible goods, these two forms of products both play important roles in consumer satisfaction and loyalty [37]. Although, a considerable amount of research is done in the field of service quality [31], [38]-[39] and product quality [40], there has been less research, if any, that has taken both service quality and product quality into consideration simultaneously. Hence, we propose to investigate the interaction effect of merchandise quality and service quality on store loyalty.

\section{OBJECTIVES AND HYPOTHESES}

The major aim of the present work aims to study the role of merchandise quality, amidst store satisfaction and service quality, in the formation of store loyalty. Specifically, following were the objectives of the study:

1) To study the main effects of store satisfaction, merchandise quality and service quality on store loyalty.

2) To study the role of merchandise quality, in the presence of service quality and store satisfaction, in the formation of store loyalty.

Based on the study objectives, following null hypotheses were framed to test the relationship between store satisfaction, service quality, merchandise quality on store loyalty:

H1: There is no significant positive effect of store satisfaction on store loyalty.

$\mathrm{H}_{2}$ : There is no significant positive effect of merchandise quality on store loyalty.

$\mathrm{H}_{3}$ : There is no significant positive effect of interaction of merchandise quality and store satisfaction on store loyalty.

$\mathrm{H}_{4}$ : There is no significant positive effect of service quality on store loyalty.

$\mathrm{H}_{5}$ : There is no significant positive effect of interaction of merchandise quality and service quality on store loyalty.

\section{Methodology}

\section{A. Data Sources}

The data were collected from a large-scale national retailer operating with focus on food and groceries. The main reason for choosing this retailer for the study is that food and groceries accounts for the largest share of revenues of the total retail market, as well as has the highest consumer demand across all income levels and various retail formats [41]. Also, the selected retailer is the first to introduce organized grocery chain in the country. 376 customers were 
contacted randomly for the study as they finish their shopping from the store. Based on the responses received by administering a structured questionnaire, 332 responses were found to be useful for further analysis.

\section{B. Questionnaire Design}

The questionnaire contains four sections, where each section represents the measurement of individual variables. The first section is about the merchandise quality; the second section is about the service quality; the third section is about the satisfaction towards the store; and the fourth section is about the store loyalty. Same survey questions, as used by Stodnick [42], were used for the merchandise quality and service quality constructs with minor modifications. Six-item scale is used for measuring merchandise quality and five-item scale is used for measuring service quality. A three-item post-experience scale is used to measure the overall satisfaction of the store shopping. Post-experience evaluation is considered because the respondents were contacted once they have finished their shopping. The scale is adopted from Jing [43]. Based on the justification given by Bridson, Evans and Hickman [14] for the use of both behavioral and attitudinal aspects in measuring loyalty, a three-item scale is used to measure the store loyalty of the customers. All the variable constructs are measured on a seven-point Likert scale ranging from 1 = strongly disagree to 7 = strongly agree.

Table 1 show the variable constructs item-wise and their reliability analysis. Favorable results in terms of coefficient alpha are observed from the reliability analysis of the scales used. All the values meet the recommended value of 0.7 [44]. The Cronbach's alpha for merchandise quality, service quality, satisfaction and store loyalty scales were $0.76,0.86$, 0.69 and 0.77 respectively.

TABLE 1. VARIABLE CONSTRUCTS AND THEIR RELIABILITY

\begin{tabular}{|c|c|}
\hline Merchandise Quality & $\begin{array}{l}\text { Relia } \\
\text { bility }\end{array}$ \\
\hline 1.Retailer offer merchandise of very high quality & \multirow{6}{*}{0.76} \\
\hline $\begin{array}{l}\text { 2.The quality of merchandise at this retailer is higher than } \\
\text { similar merchandise at other stores }\end{array}$ & \\
\hline 3.Retailer merchandise holds up well for long period & \\
\hline $\begin{array}{l}\text { 4. The merchandise I buy from this retailer is of consistent } \\
\text { quality }\end{array}$ & \\
\hline $\begin{array}{l}\text { 5.The retailers merchandise always meets my quality } \\
\text { standards }\end{array}$ & \\
\hline $\begin{array}{l}\text { 6.The quality of merchandise at this retail store consistently } \\
\text { meets my expectations }\end{array}$ & \\
\hline \multicolumn{2}{|l|}{ Service Quality } \\
\hline $\begin{array}{l}\text { 7.Retailer's service group have the skills necessary to help } \\
\text { me }\end{array}$ & \multirow{5}{*}{0.86} \\
\hline 8.I receive prompt service when I shop at this retailer & \\
\hline $\begin{array}{l}\text { 9.Retailer’s service group give caring and individual } \\
\text { attention }\end{array}$ & \\
\hline $\begin{array}{l}\text { 10.Retailer's service group are willing to go out of their way } \\
\text { to help me }\end{array}$ & \\
\hline $\begin{array}{l}\text { 11.Retailer's service group are consistently courteous and } \\
\text { friendly }\end{array}$ & \\
\hline \multicolumn{2}{|l|}{ Store Satisfaction } \\
\hline 12.I truly enjoyed by coming to this retail outlet & \multirow{3}{*}{0.69} \\
\hline 13.I am satisfied with this retail outlet & \\
\hline $\begin{array}{l}\text { 14.I think the choice to come to this retail outlet was a good } \\
\text { one }\end{array}$ & \\
\hline \multicolumn{2}{|l|}{ Store Loyalty } \\
\hline 15.I recommend this retailer to my friends and family & \multirow{3}{*}{0.77} \\
\hline 16.I would like to buy from this retail shop only & \\
\hline 17.I would like to visit this retail shop again and again & \\
\hline
\end{tabular}

\section{Sample Characteristics}

Off the 332 respondents contacted, 59\% were male and $41 \%$ were female. $92 \%$ of the respondents were of the $20-39$ years age range. $72 \%$ of the respondents have a monthly income ranging from Rs. 10,000 to Rs. 20,000 . $46 \%$ of the respondents were graduates and $34 \%$ of the respondents have a PG degree. It was found that the sample characteristics are reflective of the store's target market.

\section{Model Building}

Table 2 gives the correlations between central variables merchandise quality, service quality, store satisfaction and store loyalty. Table 2 shows positive relationships between the dependent variable, store loyalty, and independent variables, merchandise quality (0.418), service quality (0.373) and store satisfaction (0.204). Even, the relationships of store satisfaction with merchandise quality $(0.177)$ and service quality (0.332) are found to be positive. However, merchandise quality does not show significant relationship with service quality. Also, the correlations between the variables are rather weak.

Based on the favorable correlations between main variables, hierarchical regression analysis is used to further the understanding of the relationships and to test the hypotheses. We expect that the impact of merchandise quality will be more if it is interacted with store satisfaction and service quality, rather than individually. Hence, for this purpose, we used hierarchical regression to fit the two following models:

$\mathrm{SL}=\mathrm{a}+\mathrm{b}_{1}(\mathrm{SS})+\mathrm{b}_{2}(\mathrm{MQ})+\mathrm{b}_{3}$

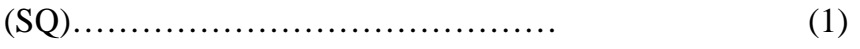

$\mathrm{SL}=\mathrm{a}+\mathrm{b}_{1}(\mathrm{SS})+\mathrm{b}_{2}(\mathrm{MQ})+\mathrm{b}_{3}(\mathrm{SQ})+\mathrm{b}_{4}(\mathrm{MQ} \mathrm{xSS})+\mathrm{b}_{5}$ (MQ x SQ)...

Where SL = store loyalty; $\mathrm{SS}=$ Store Satisfaction; $\mathrm{MQ}=$ merchandise quality; and SQ = service quality.

\section{ANALysis AND Hypotheses TESTING}

Two-way interactions are constructed between merchandise quality and satisfaction and between merchandise quality and service quality in order to study the impact of merchandise quality on store loyalty. The purpose is to investigate the effect of merchandise quality both through moderation - with store satisfaction and with service quality - and individually. The results of these analyses are shown in Table 3.

The regression results of model 1 show the direct effects of store satisfaction, merchandise quality and service quality on store loyalty. The adjusted $\mathrm{R}^{2}$ for the model 1 is 0.438 with a significant F statistic. Among the three explanatory variables

TABLE 2. CORRELATIONS BETWEEN THE VARIABLES

\begin{tabular}{|l|l|l|l|l|}
\hline & $\begin{array}{l}\text { Merchandise } \\
\text { Quality }\end{array}$ & $\begin{array}{l}\text { Service } \\
\text { Quality }\end{array}$ & $\begin{array}{l}\text { Store } \\
\text { Satisfaction }\end{array}$ & $\begin{array}{l}\text { Store } \\
\text { Loyal } \\
\text { ty }\end{array}$ \\
\hline Merchandise Quality & & -.090 & $.177^{*}$ & $.418^{* *}$ \\
\hline Service Quality & & & $.332^{* *}$ & $.373^{* *}$ \\
\hline Store Satisfaction & & & & $.204^{* *}$ \\
\hline *. Significant at the 0.05 level (2-tailed). \\
\hline **. Significant at the 0.01 level (2-tailed). \\
\hline
\end{tabular}


TABLE 3. RESULTS OF HIERARCHICAL REGRESSION ANALYSIS: MODEL 1 VERSUS MODEL 2

\begin{tabular}{|l|c|c|c|}
\hline & Coefficients (b) & t value & Significance \\
\hline Model 1 -- $\mathrm{R}^{2}=0.447 ;$ Adj. $\mathrm{R}^{2}=0.438 ;$ F value $=52.76$ & 0.000 \\
\hline Constant & 0.813 & 6.457 & 0.000 \\
\hline SS & 0.309 & 5.569 & 0.000 \\
\hline MQ & -0.102 & -1.685 & 0.094 \\
\hline SQ & 0.595 & 9.718 & 0.000 \\
\hline Model 2 $-\mathrm{R}^{2}=0.473 ;$ Adj. ${ }^{2}=0.460 ; ~ F$ value $=34.874 ; \mathrm{R}^{2}$ & 0.000 \\
\hline Change $=0.027 ;$ Sig. F Change $=0.008$ & & 0.000 \\
\hline Constant & 0.845 & 6.822 & 0.000 \\
\hline SS & 0.231 & 3.782 & 0.135 \\
\hline MQ & -0.092 & -1.502 & 0.000 \\
\hline SQ & 0.533 & 7.918 & 0.926 \\
\hline MQ x SS & -.006 & -.093 & 0.002 \\
\hline MQ x SQ & 0.188 & 3.078 & \\
\hline Dependent Variable: Store Loyalty & & \\
\hline
\end{tabular}

Used, merchandise quality is found to be non-significant ( $p>0.05)$. It can be seen that, service quality (0.595) has the higher influence on store loyalty than store satisfaction (0.309). Except merchandise quality, store satisfaction and service quality have positive effects on store loyalty. The results of the regression analysis for model 1 imply that the proposed null hypotheses $\mathrm{H}_{1}$ and $\mathrm{H}_{4}$ are rejected, while hypothesis $\mathrm{H}_{2}$ is accepted.

The regression results of model 2, along with direct effects of store loyalty, merchandise quality and service quality, show the interaction effects of merchandise quality on store loyalty. The adjusted $\mathrm{R}^{2}$ for the model 2 is 0.46 with a significant F statistic. We can see that the $\mathrm{R}^{2}$ change value is 0.027 and significant at 0.008 . This means that inclusion of the interaction effects of merchandise quality with store satisfaction and service quality explains an additional $2.7 \%$ variance in the formation of store loyalty. As in the case of model 1, in this case also, merchandise quality is found to be non-significant $(p>0.05)$. Among the two interaction effects created, the impact of store satisfaction, based on merchandise quality, on store loyalty is found to be non-significant $(\mathrm{p}>0.05)$. However, the impact of service quality, based on merchandise quality, on store loyalty is found to be significant. The results of the regression analysis for model 2 imply that, apart from reinforcing the results of regression analysis for model 1 , the proposed null hypothesis $\mathrm{H}_{5}$ is rejected, while hypothesis $\mathrm{H}_{3}$ is accepted.

\section{FINDINGS AND IMPLICATIONS}

This study tries to propose a model which furthers the understanding of store loyalty from the point of view of merchandise quality offered by the retailer. Three major outcomes of the study can be implied from the results. First, service quality has more direct influence on loyalty than store satisfaction. We reason that customers view service as more important than satisfaction in determining their loyalty towards the store. This finding is in consistent with Sivadas \& Baker-Prewitt [17] that service quality is an important factor for influencing the store loyalty. However, this is in contrast with the study done by Bei \& Chiao [37] that service quality has only indirect effect on loyalty through satisfaction. This contrasting result can be attributed to the context under which the two studies are carried out. Bei \& Chiao [37] study is based on service setting while the present study is based on retail setting varying across different geographies. Hence, the major implication is that the importance of service quality on loyalty varies across situations and it is more important than satisfaction for retailing setup.

Second, merchandise quality offered by the retailer is not found to be affecting the store loyalty directly. Merchandise is usually the core part that consumers purchase. Also, the Indian groceries retail market is witnessing a visible move towards higher level of augmentation in providing superior customer experience and not just through merchandise quality [45]. Hence, customers might not be viewing quality of merchandise as an important factor for patronizing the store. The implication for retail managers is that they just should not be satisfied that they are offering quality merchandise. They need to identify innovative ways to augment their offers in order to provide superior customer experience.

Third, a combination of quality merchandise and quality services is found to have positive effect on the store loyalty than store satisfaction clubbed with quality of merchandise offered by the retailer. An implication of this finding is that the perceptions of quality and service provided by the store contribute to the store loyalty than overall satisfaction. Customers not just seek quality merchandise but also quality services so that attitudinal and behavioral aspects of loyalty emerge in their actions. Hence, retail managers should not just focus on offering quality merchandise but also focus on providing quality services. Augmenting services that improve store satisfaction may not be sufficient to sustain store patronage [46] but they are to be provided in combination with high quality merchandise to affect store loyalty.

\section{LIMITATIONS AND FUTURE RESEARCH}

The data for the study is drawn from a single outlet and of one retail format, which may limit the generalization to other regional differences and other formats. Perhaps a large scale study by including different formats and covering wider national geographies may provide more precise insights into the concept of store loyalty. A lot of literature is available to explain the role of satisfaction, both main effects and the mediating effects, on store loyalty. Hence, the study is mainly focuses to explain the working of other variables on store loyalty. Significant percentage of variance in store loyalty remains unexplained, inducing the need for further research in the area. The study has investigated only three variables in contrast to the use of large number of variables to better explain the underlying patterns of store loyalty. Hence, other independent variables may be considered to improve the explaining power. Only few interaction effects were studied overlooking the other interaction between store satisfaction and service quality. Hence, studies including both two-way interactions and three-way interactions may help in 
explaining the power of variables in the right direction. Such studies help in identifying exactly the role of variables that they have main effects, or moderated or mediated effects through other variables in explaining the formation of store loyalty.

\section{REFERENCES}

[1] F. Reichheld, Loyalty Based Management. Harvard Business Review, 1993, March-April: p. 64-73.

[2] F. Reichheld, Lead for Loyalty. Harvard Business Review, 2001, July-August: p. 76-85.

[3] T. Jones \& J. W. Sasser, Why Satisfied Customers Defect? Harvard Business Review, 1995, Nov.-Dec. : p. 88-99.

[4] J. Heskett, T. Jones, T. Loveman, J. W. Sasser \& L. Schlesinger, Putting the Service-Profit Chain to Work. Harvard Business Review, 1994. 72 (2): p. 164-174.

[5] R. Oliver, Whence Customer Loyalty? Journal of Marketing, 1999. 63: p. 33-44.

[6] U. Yavas \& E. Babakus, Correlates of Retail Store Loyalty: An Empirical Study. In J. Kendall (Ed.), Proceedings of the 39th Annual Meeting of the Decision Sciences Institute, Atlanta. Decision Sciences Institute, 2008

[7] A. C. Toyin, A. C. David \& S. Michael, Drivers of Customer Loyalty in a Retail Store Environment. Journal of Service Science, 2008. 1 (1): 35-47.

[8] M. Osman, A Conceptual Model of Retail Image Influences on Loyalty Patronage Behavior. The International Review of Retail, Distribution and Consumer Research, 1993. 31: p. 149-166.

[9] J. Bloemer \& K. D. Ruyter, On the Relationship Between Store Image, Store Satisfaction and Store Loyalty. European Journal of Marketing, 1998. 32 (5/6): p. 499-513.

[10] J. Jacoby \& R. Chestnut, Brand Loyalty Measurement and Management, 1978: New York, Wiley.

[11] G. Day, A Two-Dimensional Concept of Brand Loyalty. Journal of Advertising Research, 1969. 9 (3): p. 29-35.

[12] R. Oliver, Satisfaction: A Behavioral Perspective on the Consumer, 1997: Boston, McGraw-Hill.

[13] K. de Wulf \& G. Odekerken-Schroder, Assessing the Impact of a Retailer's Relationship Efforts on Consumers' Attitudes and Behavior. Journal of Retailing and Consumer Services, 2003.10: p. 95-108.

[14] K. Bridson, J. Evans \& M. Hickman, Assessing the Relationship Between Loyalty Program Attributes, Store Satisfaction and Store Loyalty. Journal of Retailing and Consumer Services, 2008. 15: p. 364-374.

[15] A. Chaudhuri \& M. Holbrook, The Chain Effects from Brand Trust and Brand Affect to Brand Performance: The Role of Brand Loyalty. Journal of Marketing, 2001. 65: p. 81-93.

[16] J. Bloemer \& G. Odekerken-Schroder, Store Satisfaction and Store Loyalty Explained by Customer- and Store-Related Factors. Journal of Customer Satisfaction, Dissatisfaction and Complaining Behavior, 2002. 15: p. 68-80.

[17] E. Sivadas \& J. Baker-Prewitt, An Examination of the Relationship Between Service Quality, Customer Satisfaction and Store Loyalty. International Journal of Retail and Distribution Management, 2000. 28 (2): p. 73-82.

[18] G. Odekerken-Schroder, K. de Wulf, H. Kasper, M. Kleinjnen, J. Hoekstra \& H. Commandeur, The Impact of Quality on Store Loyalty: A Contingency Approach. Total Quality Management, 2001. 12 (3): p. 307-322.

[19] G. Day, The Capabilities of Market Driven Organizations. Journal of Marketing, 1994. 58 (4): 37-52.

[20] R. Oliver \& W. DeSarbo, Response Determination in Satisfaction Judgements. Journal of Consumer Research, 1988. 10: p. 250-255.

[21] D. Tse \& P. Wilton, Models of Consumer Satisfaction Formation: An Extension. Journal of Marketing Research, 1988. 25: p. 204-212.

[22] Y. Yi, A Critical Review of Customer Satisfaction. In V. Ziethaml, Review of Marketing, 1990: Chicago, American Marketing Association, p. 68-123
[23] C. Fornell, A National Customer Satisfaction Barometer: The Swedish Experience. Journal of Marketing, 1992. 56: p. 1-18.

[24] E. Anderson \& C. Fornell, A Customer Satisfaction Research Prospectus. In R. Rust \& R. Oliver, Service Quality: New Directions in Theory and Practice, 1994: p. 241-268.

[25] M. Brukes, V. Zeithaml \& G. Naylor, Price and Brand Name as Indicators of Quality Dimensions for Consumer Durables. Journal of Academy of Marketing Science, 2000. 28 (3): p. 359-374.

[26] J. J. Cronin, M. Brady \& G. Hult, Assessing the Effects of Quality, Value and Customer Satisfaction on Consumer Behavior Intentions in Service Environments . Journal of Retailing, 2000. 76 (2): p. 193-218.

[27] A. Parasuraman, V. Zeithaml \& L. Berry, Reassessment of Expectations as a Comparison Standard in Measuring Service Quality: Implications for Further Research. Journal of Marketing, 1994. 58: p. 111-124.

[28] D. Lee, The Effects of Product Quality and Service Quality on Consumer Satisfaction and Loyalty - A Study of Gas Station. Master Thesis, 1998: National Cheng Chi University, Taiwan.

[29] J. Jensen \& R. Markland, Improving The Application of Quality Conformation Tools in Service Firms. Journal of Service Marketing, 1996. 10 (1): p. 25-55.

[30] C. Gronroos, A Service Quality Model and its Marketing Implications. European Journal of Marketing, 1984. 18 (4): p. 36.

[31] A. Parasuraman, V. Zeithaml \& L. Berry, A Conceptual Model of Service Quality and its Implications for Future Research. Journal of Marketing, 1985. 49 (4): p. 41-50.

[32] A. Parasuraman, V. Zeithaml \& L. Berry, SERVQUAL: A Multiple-item Scale for Measuring Consumer Perceptions of Service Quality. Journal of Retailing, 1988. 64 (1): p. 12.

[33] C. Ennew \& M. Bink, Impact of Participative Service Relationships on Quality, Satisfaction and Retention: An Exploratory Study. Journal of Business Research, 1999. 46: p. 121-132.

[34] G. Fullerton, The Service Quality-Loyalty Relationship in Retail Services: Does Commitment Matter? . Journal of Retailing and Consumer Services, 2005. 12 (2).

[35] S. Olsen, Comparative Evaluation and the Relationship Between Quality, Satisfaction and Repurchase Loyalty. Journal of Academy of Marketing Sceince, 2002. 30 (3): p. 240-249.

[36] A. Zahorik \& R. Rust, Modeling the Impact of Service Quality on Profitability: A Review, 1992: Jai Press.

[37] L.T. Bei \& Y. C. Chiao, An Integrated Model for the Effects of Perceived Product, Perceived Service Quality and Perceived Price Fairness on Consumer Satisfaction and Loyalty. Journal of Consumer Satisfaction, Dissatisfaction and Complaining Behavior, 2001. 14: p. 125-140.

[38] R. Bolton \& J. Drew, A Multi Stage Model of Customers' Assessment of Service Quality and Value. Journal of Consumer Research, 1991. 17 (4): p. 371-384.

[39] A. Parasuraman, L. Berry \& V. Zeithaml, Perceived Service Quality as a Customer-focused Performance Measure: An Empirical Examination of Organizational Barriers using an Extended Service Quality Model. Human Resource Management, 1991. 30 (3): p. 335-364.

[40] D. A. Garvin, Managing Quality:The Strategic and Competitive Edge, 1988: New York: The Free Press

[41] India Brand Equity Foundation, Retail Market and Opportunities, 2007.

[42] M. Stodnick, Driving Retail Store Performance: A Service Profit Chain Perspective. Dessertation, 2005: The Ohio State University.

[43] Z. Jing, Effects of Background Musi, Voice Cues, Earcons and Gender on Psychological Ratings and Heart Rates During Product Selection on a Gift and a Mobile Phone Web Stores. Thesis, 2002: The Hong Kong University of Science and Technology, Industrial Engineering and Engineering Management, Hong Kong.

[44] J. Nunnally \& I. Bernstein, Psychometric Theory. 1995: New York, McGraw-Hill.

[45] P. Kotler, K. L. Keller, A. Koshy \& M. Jha, Marketing Management: A South Asian Perspective, 2007. ed.12 ${ }^{\text {th: }}$ : India, Pearson Education.

[46] M. J. Miranda, L. Konya \& I. Havrila, Shoppers' Satisfaction Levels are not the only Key to Store Loyalty. Marketing Intelligence and Planning, 2005. 23 (2): p. 220-232. 